PNL-2523

UC-60

\title{
Simulation of the Hourly Wind Speeds for Randomly Dispersed Sites
}

\author{
W. C. Cliff \\ C. G. Justus \\ C. E. Elderkin
}

May 1978

Prepared for the U.S. Department of Energy under Contract No. EY-76-C-06-1830

Pacific Northwest Laboratory

Operated for the U.S. Department of Energy by 
NOTICE

This report was prepared as an account of work sponsored by the United States Government. Neither the United States nor the Department of Energy, nor any of their employees, nor any of their contractors, subcontractors, or their employees, makes any warranty, express or implied, or assumes any legal liability or responsibility for the accuracy, completeness or usefulness of any information, apparatus, product or process disclosed, or represents that its use would not infringe privately owned rights.

The views, opinions and conclusions contained in this report are those of the contractor and do not necessarily represent those of the United States Government or the United States Department of Energy.

\author{
PACIFIC NORTHWEST LABORATORY \\ operated by \\ BATTELLE \\ for the \\ UNITED STATES DEPARTMENT OF ENERCY \\ Under Contract EY-76-C-06-1830
}

\author{
Printed in the United States of America \\ Available from \\ National Technical Information Service \\ United States Department of Commerce \\ 5285 Port Royal Road \\ Springfield, Virginia 22151
}

Price: Printed Copy $\$$ _; Microfiche $\$ 3.00$

- Pages Selling Price

$001-025 \quad \$ 4.00$

$026-050 \quad \$ 4.50$

$051-075 \quad \$ 5.25$

$076-100 \quad \$ 6.00$

$101-125 \quad \$ 6.50$

126-150 $\quad \$ 7.25$

$151-175 \quad \$ 8.00$

176-200 $\$ 9.00$

$207-225 \quad \$ 9.25$

226-250 $\quad 59.50$

$251-275$. $\quad \$ 10.75$

$276-300 \quad \$ 11.00$ 
PNL-2523

$\mathrm{UC}-60$

33679000492167

SIMULATION OF THE HOURLY WIND SPEEDS FOR RANDOMLY DISPERSED SITES

W. C. Cliff

C. G. Justus (a)

C. E. Elderkin

May 1978

Prepared for

the U.S. Department of Energy

under Contract No. EY-76-C-06-1830

(a) Georgia Institute of Technology Atlanta, Georgia

Pacific Northwest Laboratory

Richland, Washington 99352 


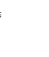


$\underline{\text { SUMMARY }}$

A technique is presented which simulates the hourly wind speeds at any number of dispersed sites within a region. The required input for the simulation is an hourly wind speed record from a single "representative site" and an estimation of the size of the region in which the sites will be located. This technique is not intended for use at any specific location but rather intended to be used for generic mission analysis type studies.

A "representative site" for this study is a site which has an annual mean wind speed representative of the annual mean wind speed at all sites under consideration. With this information, a probability density distribution for the wind speed averaged over all the sites within the region is constructed. The time history of the hourly mean wind speeds from the representative site is then used with a frequency-matching technique to establish the hourly sequence of regional average wind speeds (regional average being the average wind speed from a very large number of potential sites within a region). A Monte Carlo technique is then used to develop the hourly mean wind speeds at any number of desired sites, which are assumed to be randomly distributed throughout the area.

These simulated wind histories may then be used to simulate the hourly time history of the power output of a network of wind turbines located at these random sites, by assuming the desired number and size of wind turbines to be placed at each site. Using the simulated wind speed at each site in conjunction with the wind turbine's operating characteristics, the hourly power for each site is calculated and the calculated power for all sites is then summed to yield the total power produced by the wind turbines for that hour. The power produced at each consecutive hour is computed in the same manner, yielding a simulated time history of the power produced by the wind turbines. 


\section{FIGURES}

1 Method of Probability Matching to Determine $V_{A}$ (the average wind speed over an area). . . . .

2 Probability Distribution of wind speed in

Region for Example 1. . . . . . . . . . .

3 Uniform Spacing of $\mathrm{H}(\mathrm{V})$ and Resultant Spacing of Velocity. . . . . . . . . . . . .

\section{TABLES}

1 Example of Velocity Section for Random

Sites. . . . . . . . . . . . . . . .

B-1 Computer Program to Compute the Simulated Hourly Wind Speeds at $\mathrm{N}$ Randomly Dispersed Sites. . . . . . . . . . . . . . . B-5

B-2 Example Computation of 25 Hours of Input from a Representative Site: Region Diameter $=500 \mathrm{~km} \quad \mathrm{~B}-6$

B-3 Example Computation of 25 Hours of Input from a Representative Site: Region Diameter $=50 \mathrm{~km} \quad \mathrm{~B}-7$

B-4 Example Computation of 25 Hours of Input from a Representative Site: Region Diameter $=5 \mathrm{~km} \quad \mathrm{~B}-8$

B-5 Random Numbers Used in the Computation of Tables B-2, B-3, and B-4... . . . . . . . B-9 


\section{CONTENTS}

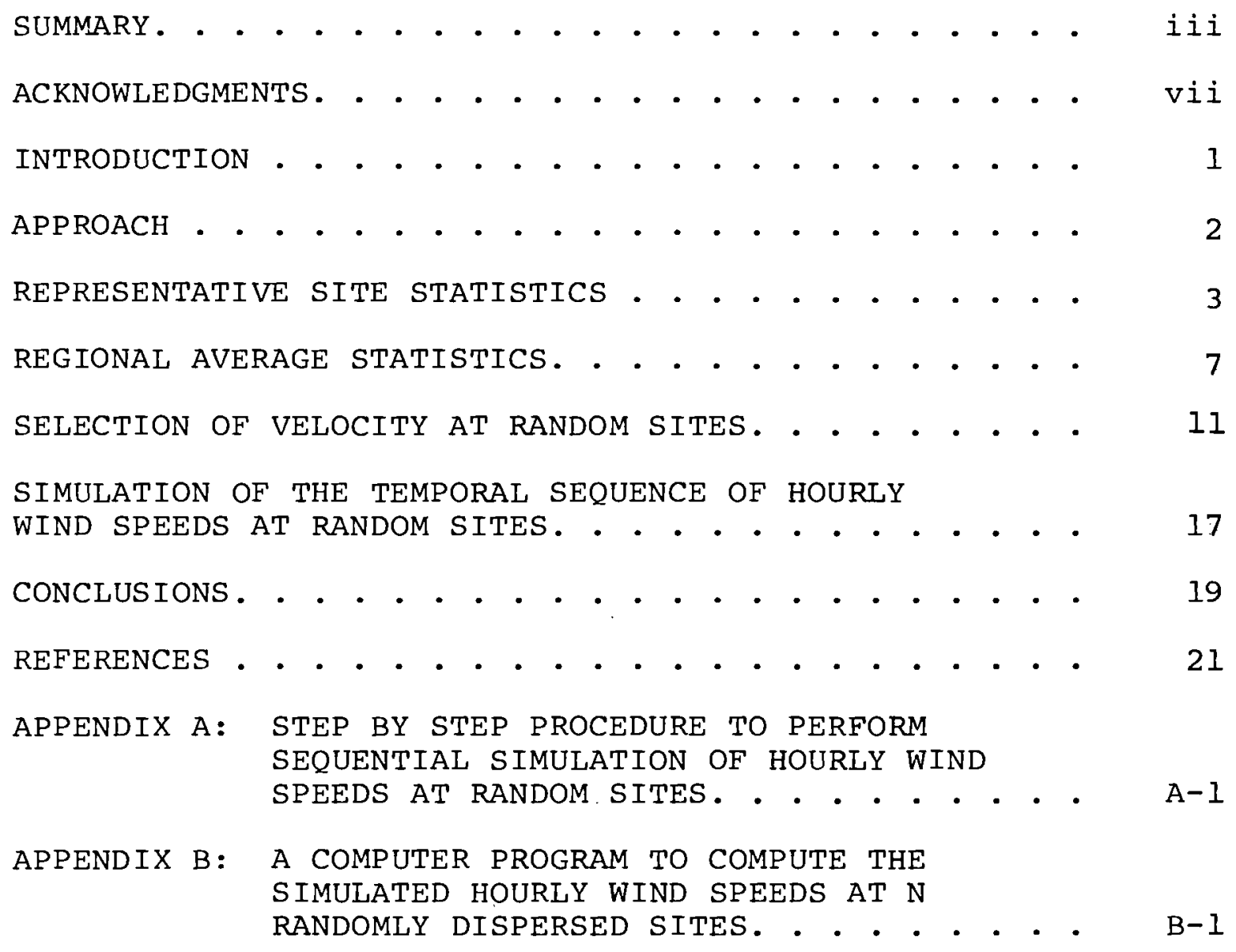




\section{ACKNOWLEDGMENTS}

The authors wish to express their appreciation to Drs. Larry L. Wendell and Stanley L. Ulanski for their review and advice.

Special thanks is given to George P. Tennyson, Donald D. Teague, and Carl Aspliden of the DOE Wind Systems Branch for their support, review and colorful advice. The authors also which to express their gratitude to Harry Wegley for preparing the computer code which appears in Appendix B. 
,

\author{
.
}


SIMULATION OF THE HOURLY WIND SPEEDS

FOR RANDOMLY DISPERSED SITES

(For use in the simulation of power produced

by wind turbines located at these sites)

W. C. Cliff, C. G. Justus, and C. E. Elderkin

\section{INTRODUCTION}

It was brought to the attention of Pacific Northwest Laboratory (PNL) that there was a need to have a method by which the output of a single anemometer could be used to simulate the power output of a wind farm with dispersed single machines or multiple machines in groups. Based upon this need, this report provides a technique by which simulated hourly wind speeds at any number of randomly dispersed sites are developed using as input only the hourly wind speed from a single anemometer and the size of region desired.* Using these simulated wind speeds at each site in conjunction with the wind turbine's characteristics, the hourly power for each site is calculated and the calculated power for all sites may then be summed to yield the total power produced by the wind turbine array for that hour. The power produced at each consecutive hour may then be computed in the same manner, resulting in a simulated time history of the power from the wind turbine array.

The model is intended for mission analysis type studies and should not be construed to be a solution to any specific region. Specific locations could require extensive knowledge of topography, exact locations of sites, etc. The model

\footnotetext{
* The technique presented in this paper may be used for wind speeds representing wind records of length 15 minutes or longer. Wind speeds representing shorter lengths should not be used however. These shorter lengths would include turbulence effects for which this paper is not intended.
} 
developed in this study uses results taken around the United states and does not represent any particular location.

\section{$\underline{A P P R O A C H}$}

Two basic inputs are required for the model: an estimate of the size of the region considered and a temporal sequence of hourly mean wind speeds from a single representative site. One could potentially use any site for which the annual mean wind speed could be scaled to the mean wind speed of other potential sites within a region. The term "regional average" will be used to define an average taken over all equivalent sites within a region. That is, only sites with the same annual mean would be included in such an average. Similarly, the annual mean wind speed of the simulated sites will statistically have the same annual. mean wind speed as the representative site, but this also could be scaled if so desired. In this paper, no scaling will be used but we will point out where it could be used if desired. Note that, in addition to the annual mean, the seasonal and diurnal variations of mean wind speed of the "representative" site are also imposed on the array simulated speeds. Therefore, if accurate modeling of seasonal and diurnal variations are desired, care should be taken to select a representative site whose seasonal and diurnal variations match those desired for the array.

Based upon statistics for the representative site, the size of the region, and equations for the correlation within a region developed by Justus $(1,2)$ (modified for random spacing about a central site), the probability distribution of the regional average wind speed is developed. By a frequencymatching technique, the temporal sequence of hourly wind speeds for a single site is used to generate a temporal sequence of hourly regional average wind speeds. A formula is then 
developed for the probability density distribution of hourly wind speeds as a function of regional size and the hourly regional average wind speed. A random sampling (Monte Carlo) technique is then used to develop the desired number of wind speed records corresponding to a desired number of randomly spaced sites. These simulated wind speed records may be used as the required input to estimate the power that specific single or multiple wind turbines would produce at each site. Summing the power from each of these sites would give a temporal sequential record of the hourly power output from the wind turbine network.

\section{REPRESENTATIVE SITE STATISTICS}

The principal input for the model is a real time sequence of hourly wind speeds from a representative site. A site is considered representative if it has the same annual mean wind speed as other typical sites within the region it represents. The model will develop simulated wind speed histories corresponding to sites randomly spaced throughout the region. Thus, the simulated wind histories will, statistically in the limit, have the same mean as the representative site.

The use of a real time sequence as the input to the model provides several important features, including a logical sequence of hourly wind speeds, which is made up of a realistic set of wind speeds, and has a realistic time correlation, diurnal variation, seasonal variation, and probability distribution. If it is desired to simulate details of seasonal and diurnal variations for the regional array, one should select a representative site which has seasonal and diurnal variations of mean wind speed similar to the regional average conditions. The wind speed at the representative site should be taken at, or modified to be equivalent to the wind speed at, a height 
equal to the hub height of the wind turbines to be used. This modification could be made after the simulation if wind turbines of various hub heights were used. The model will be estimating wind speeds at the same height as they are taken at the representative site; therefore, if another height is desired, the wind speeds must be modified by an appropriate power or log law.

The statistic (other than the mean wind speed) that is needed at the representative site is the probability distribution, $\mathrm{H}\left(\mathrm{V}_{\mathrm{S}}\right)$, of wind speed, $\mathrm{V}$. That is,

$$
H\left(V_{S}\right)=\int_{0}^{V} p(V) d V,
$$

where $p(V)$ is the probability density distribution (frequency distribution) of wind speed. If $\mathrm{H}\left(\mathrm{V}_{\mathrm{S}}\right)$ is not known, the following substitution may be made:

$$
\mathrm{H}\left(\mathrm{V}_{\mathrm{S}}\right)=1-\exp \left[-\frac{\pi}{4}\left(\frac{\mathrm{V}_{\mathrm{S}}}{\overline{\mathrm{V}}_{\mathrm{S}}}\right)^{2}\right] .
$$

This equation is a special case of the general form

$$
\mathrm{H}\left(\mathrm{V}_{\mathrm{S}}\right)=1-\exp \left[-\left(\Gamma\left(\frac{1}{\mathrm{~K}_{\mathrm{S}}}+1\right) \frac{\mathrm{V}_{\mathrm{S}}}{\overline{\mathrm{V}}_{\mathrm{S}}}\right)^{\mathrm{K}_{\mathrm{S}}}\right]
$$

when $\mathrm{K}_{\mathrm{S}}=2$, where

$\mathrm{V}_{\mathrm{S}}=$ hourly wind speed at representative site

$\overline{\mathrm{V}}_{\mathrm{S}}=$ annual mean wind speed at representative site

$\Gamma$ = gamma function

$\mathrm{K}_{\mathrm{S}}=$ Weibull shape parameter for representative site, 
Equation 1 corresponds to a $p(V)$ of:

$$
\mathrm{p}\left(\mathrm{v}_{\mathrm{s}}\right)=\frac{\pi}{2} \frac{\mathrm{v}_{\mathrm{s}}}{\overline{\mathrm{v}}_{\mathrm{s}}{ }^{2}} \exp \left[-\frac{\pi}{4}\left(\frac{\mathrm{v}_{\mathrm{s}}}{\overline{\bar{V}}_{\mathrm{s}}}\right)^{2}\right] \text {, }
$$

which is known as the Rayleigh distribution and has been shown by $\operatorname{Cliff}(3)$ and Wentink (4) to give reasonable estimates of power output from wind turbines when only the annual mean wind speed at the 10 meter level is known and is greater than about $4 \mathrm{~m} / \mathrm{s}$ (9 mph) at the 10 meter level. Justus (5) has shown that average output power is not sensitive to the shape of the wind distribution ( $K_{S}$ value) if the rated speed $V_{r}$, relative to the average speed $\bar{V}_{S}$ is in the range $0.6 \leq \bar{V}_{s} / V_{r} \leq 0.7$ and $K_{s}$ can be conviently taken as 2.0 . Justus ${ }^{(6)}$ gives values of $\mathrm{K}_{\mathrm{s}}$ (obtained from measurements around the United States) for various mean wind speeds which may yield better estimates of $\mathrm{K}_{\mathrm{S}}$ for specific locations of wind speeds; however, Corotis (7) $\mathrm{S}$ notes that with the kind of year-to-year variation expected during the operation of a wind energy conversion system, there seems to be no need to provide a model with more accuracy than the Rayleigh distribution, $\mathrm{K}_{\mathrm{S}}=2.0$. If the annual mean wind speed is less than $4.5 \mathrm{~m} / \mathrm{s}$ at hub height, Justus' report (4) may be used to derive an estimate of $\mathrm{H}\left(\mathrm{V}_{\mathrm{S}}\right)$ for the site, and the economics of using wind power for the area should perhaps be questioned. 



\section{REGIONAI AVERAGE STATISTICS}

Justus ${ }^{(2)}$ has shown empirically that a reasonable fit for the probability distribution of regional hourly average wind speed, $H\left(V_{A}\right)$, is given by

$$
\mathrm{H}\left(\mathrm{V}_{\mathrm{A}}\right)=1-\exp \left[-\left(\frac{\Gamma\left(\frac{1}{\mathrm{~K}_{\mathrm{A}}}+1\right) \mathrm{V}_{\mathrm{A}}}{\overline{\mathrm{V}}_{\mathrm{A}}}\right)^{\mathrm{K}_{\mathrm{A}}}\right],
$$

where

$$
\begin{aligned}
\mathrm{V}_{\mathrm{A}} & =\text { regional hourly wind speed } \\
\overline{\mathrm{V}}_{\mathrm{A}} & =\overline{\mathrm{V}}_{\mathrm{S}}=\text { regional annual mean wind speed } \\
\mathrm{K}_{\mathrm{A}} & =\text { constant depending on regional size and } \mathrm{K}_{\mathrm{S}} \\
\Gamma & =\text { gamma function. }
\end{aligned}
$$

(NOTE: We have previously stated that $\bar{V}_{S}$ for the representative site is equal to $\overline{\mathrm{V}}_{\mathrm{A}}$ )

Justus (2) gives $\mathrm{K}_{\mathrm{A}}$ as a function of the average correlation between sites within the region, the Weibull shape parameter for the representative site $\left(\mathrm{K}_{\mathrm{s}}\right)$, and the number of sites. This function of $\mathrm{K}_{\mathrm{A}}$ (for a large number of sites) becomes:

$$
\frac{\mathrm{K}_{\mathrm{A}}}{\mathrm{K}_{\mathrm{S}}}=\rho^{-0.543} .
$$

Here, $\rho$ is the average correlation between sites and is defined as

$$
\rho=\exp \left[-\left(\frac{\bar{r}}{520}\right)^{0.57}\right] \text {, }
$$


where $\vec{r}$ is in $\mathrm{km}$ and is equal to the average distance between sites.

For a circle of diameter D (radius $R$ ), $\bar{r}$ calculated about the center of the circle is equal to

$$
\bar{r}=\int_{0}^{\mathrm{R}} \operatorname{rp}(r) \mathrm{dr}=\frac{2 \mathrm{R}}{3}=\frac{\mathrm{D}}{3}^{\star},
$$

where

$$
p(r)=\frac{2 r}{R^{2}}
$$

Thus, for a circle, Equation (6) becomes

$$
\rho=\exp \left[-\left(\frac{D}{1560}\right)^{0.57}\right]
$$

Equations (4) through (8) define the probability distribution of the hourly wind speed averaged over the region. Note that for regions less than $2000 \mathrm{~km}$ in diameter, $\Gamma\left(1 / \mathrm{K}_{\mathrm{A}}+1\right)$ (from Equation (5)) has a value within $3 \%$ of $(\pi / 4)^{1 / 2}$. Therefore, it is recommended that this approximation be used since the use of a model of this nature would have questionable value for regions on the order $2000 \mathrm{~km}$ or greater.

\footnotetext{
*Justus and Mikhail (2) calculated $\bar{r}$ for a large number of sites randomly spaced within a near circular region and found $\bar{r} \simeq D / 2.64$. Thus for a noncentral representative site one could use

$$
\bar{r}=\frac{D}{2.64} \text { and } \rho=\exp \left[-\left(\frac{D}{1373}\right)^{0.57}\right] \text {. }
$$
}


The next wind statistic required for the model is the probability distribution of hourly wind speed throughout the region, $\mathrm{H}\left(\mathrm{V}_{\mathrm{ts}}\right)$, given a mean wind speed averaged over the equivalent sites within the region. This probability distribution has two boundary conditions. First, when the size of the region in question shrinks to a point (single site), the density distribution, $\mathrm{P}\left(\mathrm{V}_{\mathrm{ts}}\right)$, must become a Dirac delta function at the regional average hourly wind speed. Second, equating time and space statistics and letting the regional size approach global extent, the distribution must approach the distribution given by Equation (1). Using the correlation parameter, $\rho$, defined in Equation (8), the required form of the equation for the probability distribution of wind speed, $H\left(V_{t s}\right)$ in the region is expressed as:

$$
H\left(v_{t s}\right)=1-\exp \left[-\left(\frac{\Gamma\left(\frac{(1-\rho)^{c}}{K_{s}}+1\right) v_{t s}}{v_{A}}\right)^{K_{s} /(1-\rho)^{c}}\right]
$$

where $c$ is an empirical constant estimated to be equal to 0.5 based upon unpublished results of Justus' array work. * Thus $\mathrm{H}\left(\mathrm{V}_{t \mathrm{~s}}\right)$, for the present time, will be computed by the following.

$$
H\left(v_{t s}\right)=1-\exp \left[-\left(\frac{\Gamma\left(\frac{(1-\rho)^{0.5}}{K_{S}}+1\right) v_{t s}}{v_{A}}\right)^{K_{S} /(1-\rho)^{0.5}}\right]
$$

\footnotetext{
*These results will appear in the next Annual Report to the DOE from the Georgia Institute of Technology by C. G. Justus.
} 



\section{SELECTION OF VELOCITY AT RANDOM SITES}

The frequency distribution for hourly wind speeds in a region has been given by Equations (9) and (10). However, the distribution is a function of the hourly wind speed averaged over the region. The technique employed to obtain the hourly regional average wind speed is to take the hourly wind speed from the representative site and equate the value of the representative site's probability distribution at this value of wind speed to the probability distribution of the region, and solve for the appropriate hourly regional average wind speed.

If one uses Equation (I) as an approximation to the probability distribution for a single site (i.e., $\mathrm{K}_{\mathrm{S}}=2$ ), the probability matching yields*

$$
\mathrm{v}_{\mathrm{A}}=\frac{\overline{\mathrm{V}}_{\mathrm{s}}}{\Gamma\left(\frac{1}{\mathrm{~K}_{\mathrm{A}}}+1\right)}\left[\frac{\pi}{4}\left(\frac{\mathrm{V}_{\mathrm{s}}}{\overline{\mathrm{V}}_{\mathrm{s}}}\right)^{2}\right]^{1 / \mathrm{K}_{\mathrm{A}}}
$$

which, when the region is less than $2000 \mathrm{~km}$ in diameter, may be approximated by

$$
\mathrm{V}_{\mathrm{A}} \simeq \mathrm{C}_{1} \mathrm{~V}_{\mathrm{s}}^{2 / \mathrm{K}_{\mathrm{A}}}
$$

where

$$
c_{1}=\left[\left(\frac{4}{\pi}\right)^{\frac{1}{2}} \bar{v}_{\mathrm{s}}\right]^{\frac{\mathrm{K}_{\mathrm{A}}-2}{\mathrm{~K}_{\mathrm{A}}}}
$$

\footnotetext{
*For the case when $K_{S} \neq 2$, Equation (2) and (4) should be set equal and $V_{A}$ solved for. Equation Bl6 of Ref. 1 also gives this result.
} 
From Equation (5),

$$
\mathrm{K}_{\mathrm{A}}=2 p^{-0.543}
$$

and from Equation (8),

$$
\rho=\exp \left[-\left(\frac{D}{1560}\right)^{0.57}\right]
$$

where $D(\mathrm{~km})$ is the diameter of the region in question.

Example Case 1

$$
\text { Diameter of region } \begin{aligned}
=500 \mathrm{~km} \\
\overline{\mathrm{V}}_{\mathrm{S}}=\overline{\mathrm{V}}_{\mathrm{A}}=10 \mathrm{~m} / \mathrm{s} \\
\mathrm{V}_{\mathrm{S}}=5 \mathrm{~m} / \mathrm{s}
\end{aligned}
$$

Equation (11) gives $\mathrm{V}_{\mathrm{A}}=6.09 \mathrm{~m} / \mathrm{s}$

Equation (12), which is an approximation to Equation (11), gives

$$
\mathrm{V}_{\mathrm{A}}=6.11 \mathrm{~m} / \mathrm{s} \text {. }
$$

The differences in the values generated by Equations (11) and (12) are well within the accuracy of the presented model. It is therefore recommended that Equation (12) be used if the regional diameter is less than $2000 \mathrm{~km}$.

Figure 1 graphically depicts the probability matching process for this example.

With the values of $V_{A}$ and $p$ solved, Equation (10) is completely defined. The following technique will be used to establish the wind speed at each of $\mathrm{N}$ sites. First, Equation (10) is rewritten as: 


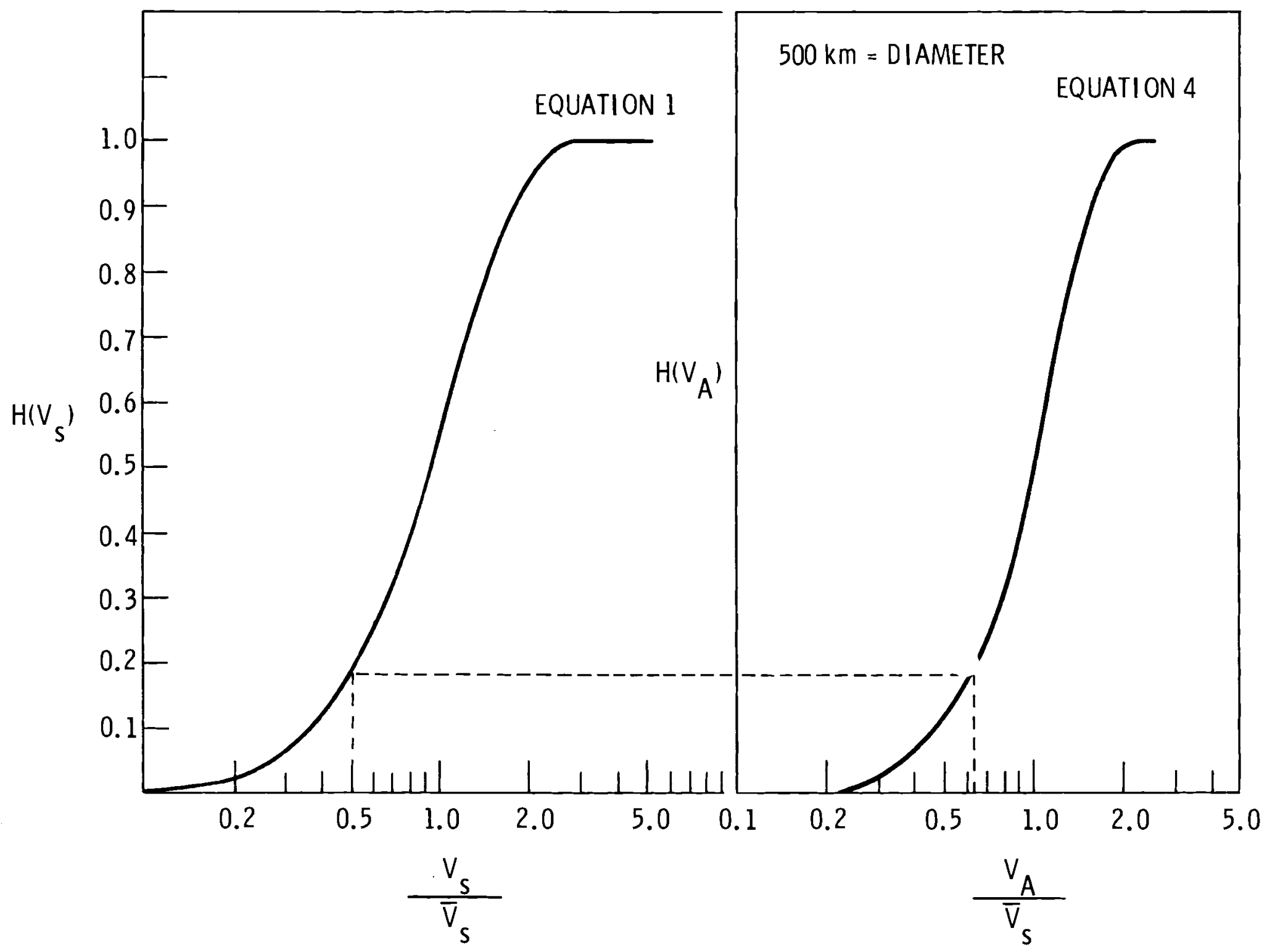

FIGURE 1. Method of Probability Matching to Determine $\mathrm{V}_{\mathrm{A}}$ (The Average Wind speed Over an Area)

(-- Indicates frequency matching for Example 1) 


$$
v_{t s}=\frac{V_{A}\left[-\ln \left(1-H\left(v_{t s}\right)\right)\right]^{\frac{(1-\rho)^{0.5}}{2}}}{\Gamma\left[\frac{(1-\rho)^{0.5}}{2}+1\right]}
$$

Next, a random number generator (or table of random numbers) is used to produce $\mathrm{N}$ random numbers with values between 0.0 and 1.0 , each representing sites 1 to $N$. These numbers are then used as values of $\mathrm{H}\left(\mathrm{V}_{t s}\right)$ and the corresponding values of $V_{\text {ts }}$ are solved for. Thus the first random number is used for $H\left(V_{t s}\right)$ in Equation (14), resulting in the velocity, $V_{t s}$, for the first site; the second random number is used for $H\left(V_{t s}\right)$ in Equation (14), resulting in the velocity at the second site, and so on, until the $\mathrm{N}$ desired has a velocity, $V_{t s}$, corresponding to the hourly wind speed at the Nth site. Table 1 is an example of 14 wind speeds selected for Example Case 1 using a random number table. Figure 2 graphically depicts the technique used to find the velocity at the random sites. The first four random numbers from Table 1 were used in Figure 2 to graphically show the process of relating the random numbers used as $\mathrm{H}\left(\mathrm{V}_{\mathrm{ts}}\right)$ values to corresponding values of velocity. 
TABLE 1. Example of Velocity Selection for Random Sites (Random numbers taken from

a table of random numbers)

\begin{tabular}{|c|c|c|c|}
\hline Site No. & Random Number $(\mathrm{a})$ & $=\mathrm{H}\left(\mathrm{V}_{\mathrm{ts}}\right)$ & $\begin{array}{c}V_{t s}(\mathrm{~m} / \mathrm{s}) \\
(D=500 \mathrm{~km})\end{array}$ \\
\hline 1 & 0.133 & & 3.67 \\
\hline 2 & 0.168 & & 3.98 \\
\hline 3 & 0.741 & & 7.52 \\
\hline 4 & 0.920 & & 9.18 \\
\hline 5 & 0.247 & & 4.57 \\
\hline 6 & 0.367 & & 5.32 \\
\hline 7 & 0.008 & & 1.47 \\
\hline 8 & 0.229 & & 4.45 \\
\hline 9 & 0.022 & & 2.02 \\
\hline 10 & 0.516 & & 6.16 \\
\hline 11 & 0.073 & & 3.00 \\
\hline 12 & 0.765 & & 7.69 \\
\hline 13 & 0.973 & & 10.29 \\
\hline 14 & 0.460 & & 5.85 \\
\hline
\end{tabular}

Mean $=5.36 \mathrm{~m} / \mathrm{s}$

(NOTE: These average values would equal $6.11 \mathrm{~m} / \mathrm{s}$ if a very large number of random numbers were used. Each new set of random numbers would produce a different mean value for the random sites; this is required because the processes involved are stochastic. Note that a larger correlation value (smaller D) will always force $V_{\text {ts }}$ toward the mean value of the area. If $\rho=1$, all $\mathrm{V}_{t s}$ would equal the area average.

(a) New random numbers must be selected for each hourly computation. 


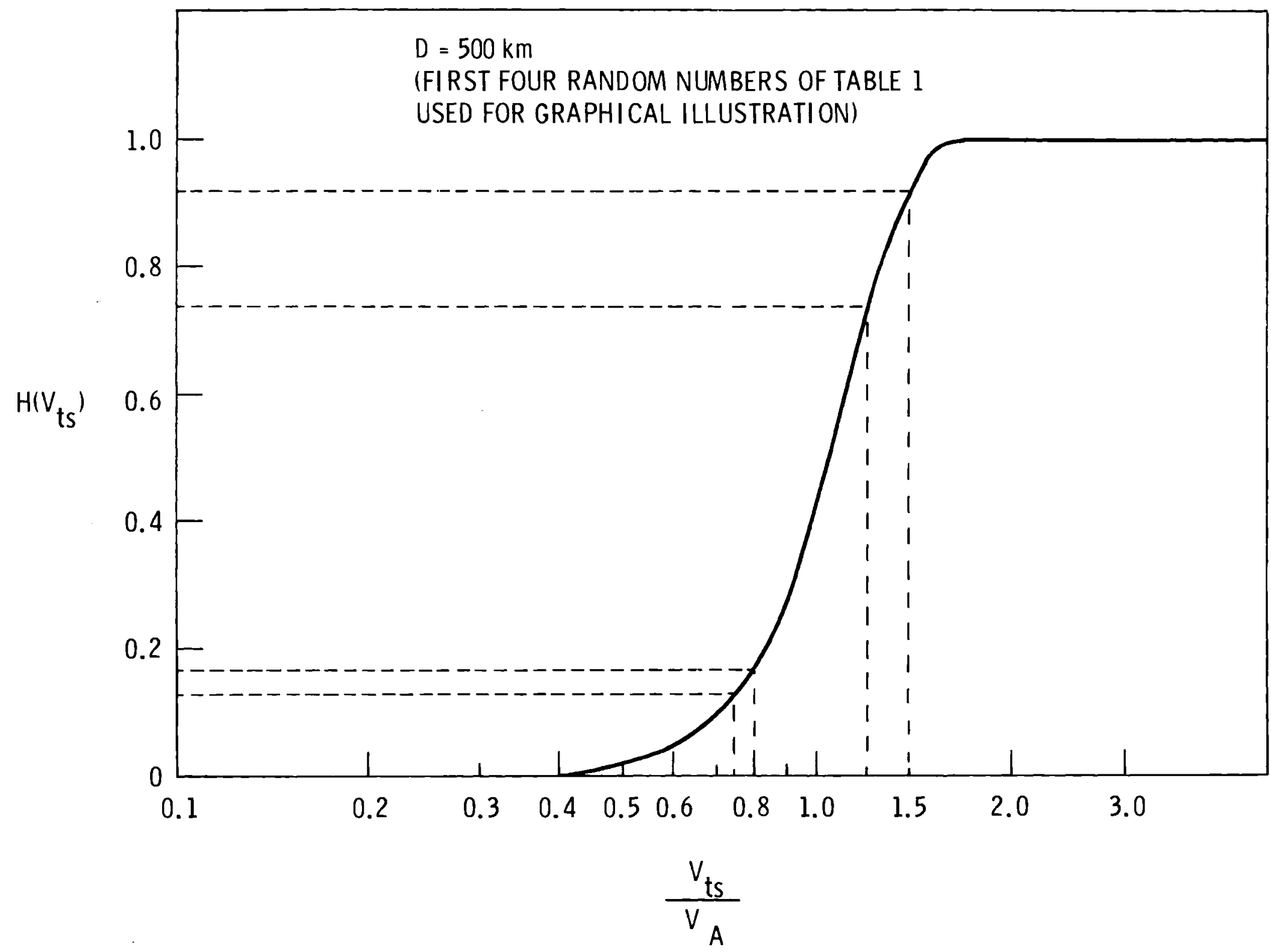

FIGURE 2. Probability Distribution of Wind Speed in Region for Example 1 
The values of the next hourly wind speed at each of the sites are determined by taking the value of the next hourly wind speed from the representative site, solving for $v_{A} u s i n g$ Equation (12), selecting $N$ new random numbers, and solving for the hourly wind speed at each site $V_{\text {ts }}$ using Equation (14). This process is repeated until the desired length of record for the random sites has been established.

To simulate the time sequence of power produced by wind turbines at the sites, one assumes that a desired size and number of machines is located at the $\mathrm{N}$ random sites. Use of the wind turbine characteristics, together with the time sequence of the simulated wind speeds at each site, yields a time sequence of wind turbine power produced at each site. The summation of these wind turbine powers from the $N$ sites results in a time sequence of power output from the wind turbines. This modeling technique relies on the fact that a uniform probability density distribution of $\mathrm{H}(\mathrm{V})$ results in a probability density distribution of wind speed, $p(V)$, equal to $\mathrm{dH}(\mathrm{V}) / \mathrm{dV}$. This equality is desired so that the simulated wind records will have the proper statistical properties. This effect is graphically illustrated in Figure 3, where $H(V)$ was sampled at 0.05 intervals and the corresponding velocities were graphically located. 


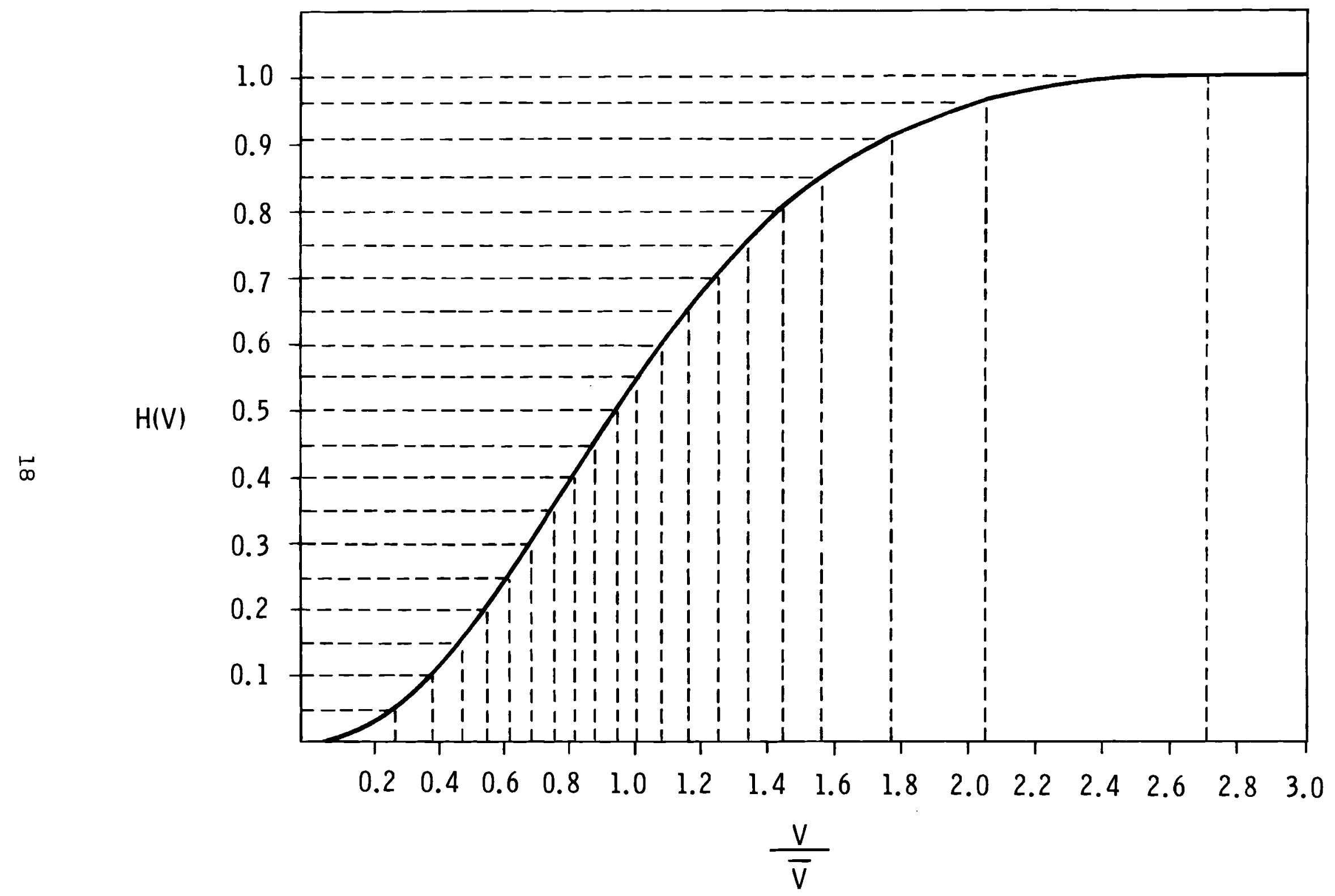

FIGURE 3. Uniform Spacing of $H(V)$ and Resultant spacing of velocity 


\section{CONCLUSIONS}

This report develops a model by which simulations of hourly wind speeds may be generated for any desired number of random sites with a region of a given size. Using these wind histories in conjunction with the operating characteristics of wind turbines, simulations of power output time histories from wind turbine arrays may be generated. 


\section{REFERENCES}

1. C. G. Justus, W. R. Hargraves, Wind Energy Statistics for Large Arrays of Wind Turbines (Great Lakes and Pacific Coast Regions). RLO/2439-77/2, Georgia Institute of Technology, Atlanta, GA, May 1977.

2. C. G. Justus, A. S. Mikhail, Energy Statistics for Large Wind Turbine Arrays. RLO/2439-78/3, Georgia Institute of Technology, Atlanta, GA, May 1978.

3. W. C. Cliff, The Effect of Generalized Wind Characteristics on Annual Power Estimates from wind Turbine Generators. PNL-2436, Battelle, Pacific Northwest Laboratories, Richland, WA 99352, October 1977.

4. T. Wentink, Wind Power Potential of Alaska: Part II. Wind Duration Curve Fits and Output Power Estimates for Typical Windmills. UAG R-240, University of Alaska, Fairbanks, $\mathrm{AK}$, August 1976.

5. C. G. Justus, Winds and Wind System Performance. Franklin Institute Press, Philadelphia, PA, 1978 .

6. C. G. Justus, W. R. Hargraves, and A. Mikhail, Reference Wind Speed Distributions and Height Profiles for Wind Turbine Design and Performance Evaluation Applications. ORO/5108-76/4, Georgia Institute of Technology, Atlanta, GA, August 1976 .

7. R. B. Corotis, Stochastic Modeling of Site Wind Character-

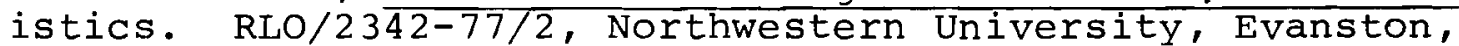
II, September 1977. 

APPENDIX A

STEP-BY-STEP PROCEDURE TO PERFORM SEOUENTIAL SIMULATION OF HOURLY WIND SPEEDS AT RANDOM SITES

$A-1$ 



\section{APPENDIX A}

STEP-BY-STEP PROCEDURE TO PERFORM SEQUENTIAL SIMULATION OF HOURLY WIND SPEEDS AT RANDOM SITES

1. From a representative site ${ }^{(a)}$ obtain the probability distribution, $\mathrm{H}\left(\mathrm{V}_{\mathrm{s}}\right)$, for wind speed or use

$$
\mathrm{H}\left(\mathrm{V}_{\mathrm{S}}\right)=1-\exp \left[-\frac{\pi}{4}\left(\frac{\mathrm{V}_{\mathrm{S}}}{\overline{\bar{V}}_{\mathrm{S}}}\right)^{2}\right]
$$

as an approximation, where $V_{S}$ is wind speed and $\bar{V}_{\mathbf{S}}$ is the annual average wind speed.

2. Calculate the quantity $\mathrm{K}_{\mathrm{A}}$ :

$$
\mathrm{K}_{\mathrm{A}}=2 \rho^{-0.543}
$$

where

$$
\rho=\exp \left[-\left(\frac{\mathrm{D}}{1560}\right)^{0.57}\right]
$$

and $\mathrm{D}$ is the diameter of the region being considered.

3. Using a time sequence of hourly values of wind speed, $V_{\mathbf{s}^{\prime}}$ from the representative site, compute a time sequence of regional hourly wind speeds, $V_{A}$, from the following:

$$
\mathrm{V}_{\mathrm{A}}=\mathrm{C}_{1} \mathrm{~V}_{\mathrm{s}}^{2 / \mathrm{K}_{\mathrm{A}}}
$$

(a) A site is considered representative if its annual mean wind wind speed is representative of the annual mean wind speed at other typical sites within the region. This simulation scheme develops wind histories at random locations, but the expected annual mean at each site is the same. 
where

$$
C_{1}=\left[\left(\frac{4}{\pi}\right)^{\frac{1}{2}} \bar{v}_{S}\right]^{\frac{\mathrm{K}_{A}-2}{\mathrm{~K}_{A}}}
$$

4. For each hour, select $N$ random numbers, $H\left(V_{t s}\right)$, between 0 and 1 , where $\mathrm{N}$ equals the number of sites desired (i.e., for each hour let the first random number represent the first site, the second random number represent the second site, etc.).

5. For each random number, $H\left(V_{t s}\right)$, calculate a corresponding velocity, $v_{t s}$.

$$
v_{t s}=\frac{V_{A}\left[-\ln \left(1-H\left(V_{t s}\right)\right)\right] \frac{(1-\rho)^{0.5}}{2}}{\Gamma\left[\frac{(1-\rho)^{0.5}}{2}+1\right]}
$$

6. The values calculated in step 5 now give $N$ simulated wind speed records for the $\mathrm{N}$ desired sites. These wind speed records may be used in conjunction with desired wind turbine operating characteristics to produce time histories of the wind power developed at each site. The sum of the power generated each hour at all sites then simulates a time history of the total power produced by the wind turbines located at the sites. The postulated wind turbines may be single or multiple units at each site. 
APPENDIX B

A COMPUTER PROGRAM TO COMPUTE THE SIMULATED

HOURLY WIND SPEEDS AT $N$ RANDOMLY DISPERSED SITES

B-1 


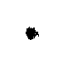




\section{APPENDIX B}

A COMPUTER PROGRAM TO COMPUTE THE SIMULATED HOUTRY WIND SPEEDS FOR RANDOMLY DISPERSED SITES

This appendix presents a computer program in the form of a subroutine which will compute simulated hourly wind speeds for any desired number, $N$, of hypothetical sites randomly dispersed throughout a region of specified size. The subroutine is designed to be used with any program which will provide it with a wind speed from a single anemometer within the region. The small driving program, shown with the subroutine on Table B-1, was assembled to test the subroutine. An example case is presented to show the effect of region size on the simulated wind speed sequences. Tables B-2, B-3 and B-4 each present 10 wind speed simulations for regions with diameters $500 \mathrm{~km}, 50 \mathrm{~km}$ and $5 \mathrm{~km}$, respectively. The same set of random numbers, Table B-5, were used in each case for the computation of the simulated wind speeds. It is seen from Tables B-2, B-3 and B-4 that the smaller the region size, the closer the simulated wind speeds approach the representative site's wind speed.

Inputs to the driving program for the test case are:

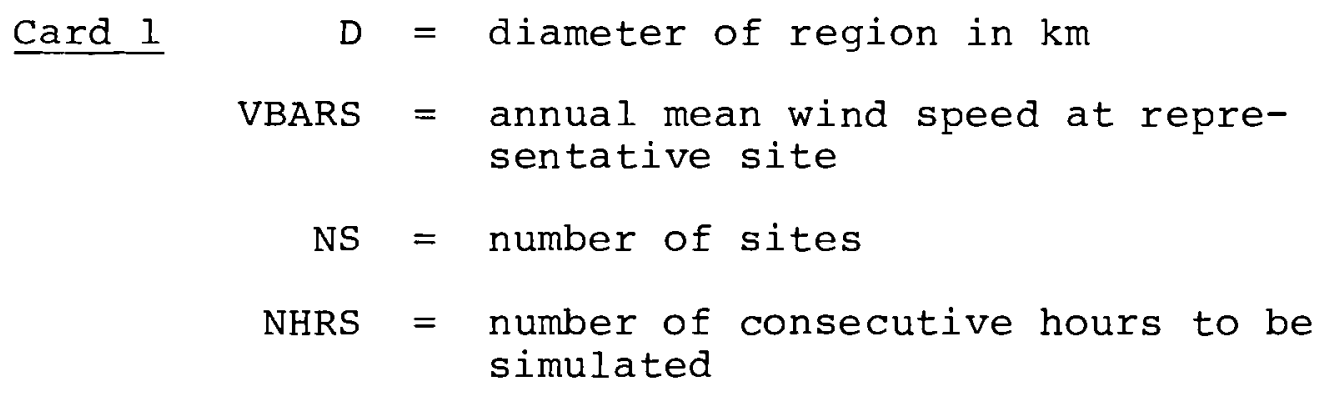

Cards $2 \quad V_{s}=$ consecutive values of the hourly wind speed at the representative site to be used as input for the simulation scheme 
The probability distribution for the representative site as defined by Equation $(A-1)$ is used in subroutine NSITES. 
TABLE B-1. Computer Program to Compute the Simulated Hourly wind Speeds at $N$ Randomly Dispersed Sites

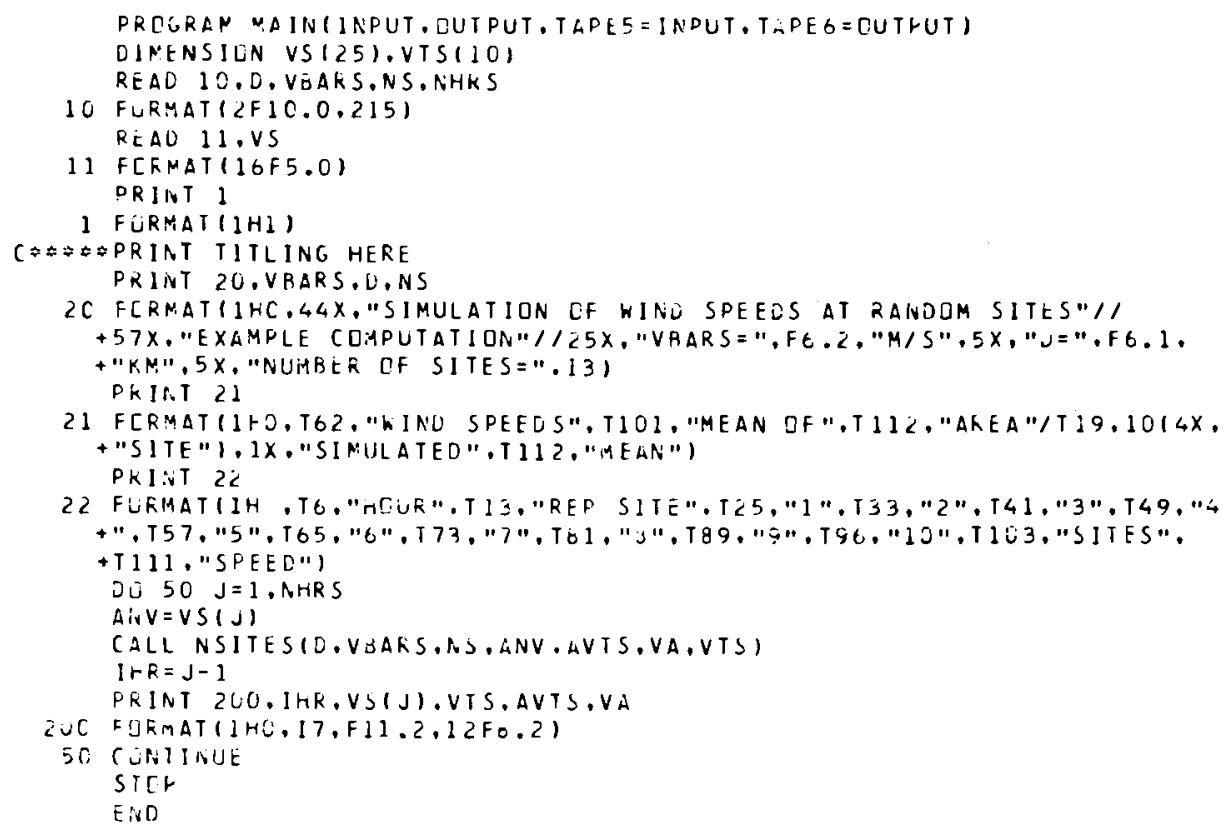

SUBRTUTINE NSITESIC.VIOARS.NS, ANV, AVTS,VA,VTSI

C\#AOOD- OIAMETER LF THE AREA (K!I) (FKSH MAIU)

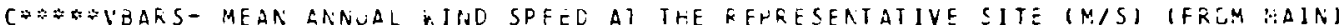

C

$(\because \Rightarrow \Rightarrow \approx$ (FRL, M MAIN)

$C \nRightarrow \Rightarrow \Rightarrow A N V-A$ SINGLE HUURLY IIIND SPEEE AT THE REPRESENTATIVE SITE (M/S)

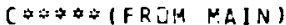

$C \neq \$ \angle V T S-$ VARIABLE USEC TU SUM NS SIIE WINE SPEEQS. FINALLY AVTS IS SET = IJ

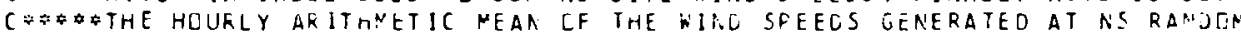

$C \approx$ SITES (COMPUTED IN NSITES)

$C \because \#$ \#A- MEAN WIND SPEED IIF THE ENTIRE AREA (M/SI (CJMPUTEL IN RISITES)

C\%OVTS-ARRAY CONTAININE HLURLY WIND SPEED (M/S) FUR EACH OF THE RANDUM SITES

(*⿻肀

DIMENSICN GAM(E1), VTS (1)

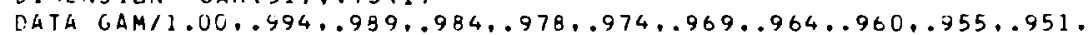

$+.947, .944, .940, .936, .933, .930, .927, .924, .921, .918 \ldots 916 . .913 \ldots 911$,

$+.909 \ldots 906 \ldots 904, .902, .901, .899, .897 \ldots 896, .895, .843 \ldots .092 \ldots 891 \ldots 694$.

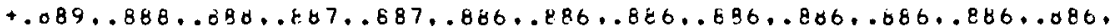

$+.886 /$

DATA PI/3.1416/

DATA KMOD $/ 0$

IF (KMOD.GE.-1) GU TO 15

RHD $=E X P(-1 D / 1560) \neq .57$.

ERHE $=S O R T(1 .-R H U) / 2$.

$R K A=2 . \neq(R H D \neq \neq(-.543))$

$C 1=(S 6 R T(4 . / P I) \neq V B A R S) \neq \geqslant((R K A-2.) / R K A)$

KRHII $=$ ( ERHC+1.) $\$ 100 .-99$.

$G R H C=G A M(K R H O)$

$K M O U=1$

15 CENTIAUE

$V A=C I * A N V *(2 . / K K A)$

$\angle \vee T S=0$.

DE $25 \quad 1=1, N S$

HVTS $=K A N F(A)$

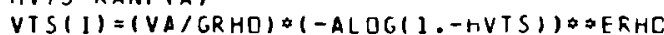

AVTS =AVTS+VTS(I)

25 CUNTINUE

AVTS =AVTS/FLOAT (NS)

RETURA

END 
SIMULATIOV OF WINO SPEEDS AT RANDOM SITES

EXAMPLE COMPUTATION

VAARS= $10.00 \mathrm{M} / \mathrm{S}$ D. $500.0 \mathrm{KM}$ NUMBER OF SITESE 10

\begin{tabular}{|c|c|c|c|c|c|c|c|c|c|c|c|c|c|}
\hline HOIIR & REP SITE & SITE & $\operatorname{SITE}_{2}$ & SITE & SITE & ${ }_{5}^{51 T E}$ & $\begin{array}{l}\text { INO SD } \\
\text { SITE } \\
6\end{array}$ & $\begin{array}{l}\text { EDS } \\
\text { SITE }\end{array}$ & SITE & SITE & site & $\begin{array}{l}\text { MEAN OF } \\
\text { SI MULATED } \\
\text { SITES }\end{array}$ & $\begin{array}{l}\text { RREA } \\
\text { MEAN } \\
\text { SPEED }\end{array}$ \\
\hline$n$ & 10.00 & 10.99 & $16: 34$ & 13.21 & 0.25 & 9.79 & $2.2 B$ & 8.01 & 9.34 & 12.09 & 9,11 & 9.84 & 10.30 \\
\hline 1 & 11.0 & 6.65 & 14.90 & 11.07 & 6.01 & 8.64 & 12.26 & 5.69 & 20.22 & 19.09 & 13.07 & 11.04 & 11.10 \\
\hline$?$ & 12.00 & 14.16 & 9.35 & 7.04 & 16.42 & 15.65 & 12.18 & 3.72 & 9.66 & 10.05 & 18.40 & 12.44 & 11.82 \\
\hline ? & 12.83 & 9.85 & 13.31 & 18.18 & 17.78 & 12.30 & 11.15 & 17.45 & 18.99 & 13.44 & 0.74 & 14.12 & 12.43 \\
\hline 4 & $13.4 \mathrm{~h}$ & 19.47 & 12.37 & 14.33 & 12.17 & 12.30 & 9.45 & 16.16 & 13.88 & 12.13 & 12.74 & 13.40 & 12.89 \\
\hline a & 13.96 & 19.A2 & 9.27 & 17.68 & 8.29 & 17.96 & 15.30 & 19.96 & 11.39 & 9.92 & 20,32 & 13.99 & 13.17 \\
\hline ^ & 10.00 & 11.69 & 7.06 & 10.83 & 15.26 & 15.05 & 13.30 & 8.91 & 11.79 & 7.60 & 18.21 & 11.97 & 13.27 \\
\hline 7 & 13.86 & 15.74 & 15.91 & $14 . A 2$ & 3.93 & 6.41 & 21.04 & 12.15 & 11.71 & 14.35 & 19.11 & 13.52 & 13.17 \\
\hline D & 13.44 & 6.41 & 13.70 & $19.9 \mathrm{~A}$ & 13.65 & 7.50 & 16.49 & 13.05 & 10.07 & 12.24 & 9.42 & 12.23 & 12.09 \\
\hline a & 12.03 & 13.71 & $j 6.22$ & 7.54 & 12.53 & 13.99 & 15.26 & 14.74 & 12.42 & 15.37 & 13.05 & 13.48 & 12.43 \\
\hline in & 12.00 & 9.59 & $11.5 \mathrm{~A}$ & 16.01 & 15.36 & 4.85 & 17.15 & 16.26 & 16.26 & 13.86 & 11.75 & 13.33 & 11.82 \\
\hline 11 & 11.00 & 7.69 & 7.46 & $8, \cap 9$ & 13.34 & 6.45 & 7.93 & 14.01 & 17.72 & 11.38 & 11.01 & 10.93 & 11.10 \\
\hline $1 ?$ & 10.00 & 12.53 & A.91 & 11.02 & 10.29 & 10.75 & 9.13 & 12.93 & 14.63 & 0.12 & 5.09 & 10.60 & 10.30 \\
\hline$i 1$ & 8.96 & 11.91 & 14.15 & 11.91 & 9.48 & 9.61 & 15.11 & 15.27 & 24.14 & 11.76 & 7.83 & 12.12 & 9.49 \\
\hline 14 & 8.00 & 11.36 & 12.89 & 11.75 & 7.43 & 11.32 & 8.32 & 8.99 & 22.17 & 7.37 & 6.94 & 9.05 & 0.71 \\
\hline 15 & 1.17 & 9.50 & $3: 42$ & 5.44 & 3.81 & 4.14 & 9.84 & 0.10 & 1.90 & 4.45 & 7.01 & 6.37 & 0.02 \\
\hline 16 & 6.54 & 2.92 & 5004 & 11.22 & 0.02 & 8.29 & 11.75 & 12.01 & 8.10 & 7.59 & 6.29 & 0.20 & 7.48 \\
\hline i7 & 6.14 & 5.25 & $7: 67$ & 7.93 & 6.52 & 6.73 & 8.24 & 4.05 & 7.71 & 7.23 & 1.78 & 7.00 & 7.14 \\
\hline 19 & 0.00 & 5.41 & 9.60 & 4.36 & 1.00 & 5.67 & 0.17 & 4.60 & 5.36 & 9.26 & 5.64 & 6.32 & 7.01 \\
\hline 10 & 0.14 & $12 \cdot 38$ & $1:>8$ & 5.68 & 3.13 & 5.09 & 1.25 & 3.95 & 7.33 & 7.60 & 8.02 & 0.25 & 7.14 \\
\hline $2^{n}$ & 6.54 & 3.14 & 3.55 & 3.71 & 6.81 & 7.03 & 9.68 & 6.77 & 9.35 & 6.83 & 7.01 & 6.39 & 7.40 \\
\hline 21 & 7.17 & 4.64 & $0: 36$ & 0.00 & 9.12 & 9.73 & 5.36 & 12.40 & 6.84 & 0.22 & 20.04 & 0.43 & 8.02 \\
\hline $2 ?$ & 0.00 & 6.81 & 9.23 & 10.13 & 5.30 & 5.30 & 11.26 & 13.96 & 5.09 & 0.02 & 2.96 & 7.70 & 0.71 \\
\hline 23 & 3.96 & 11.01 & 3.63 & 7.36 & 10.13 & 6.12 & 10.28 & 6.63 & 12.43 & 7.99 & 0.07 & 0.37 & 9.49 \\
\hline 26 & 10.00 & 4.94 & 4.74 & 7.20 & 6.23 & 13.65 & 1.00 & 0.45 & 7.01 & 4.36 & 4.73 & 7.01 & 10.30 \\
\hline
\end{tabular}

TABLE B-2. Example Computation of 25 Hours of Input from a Representative Site: Region Diameter $=500 \mathrm{~km}$. (For this example the wind velocity at the representative site was defined by $v_{s}=10+4 \sin \pi t / 12$ where $t$ represented hours.) 
STMILATION TE WIND SPEEDS AT RANDOM SITFS

EXAMPLE COMPUTATION

\begin{tabular}{|c|c|c|c|c|c|c|c|c|c|c|c|c|c|}
\hline \multirow[b]{2}{*}{ HOIIR } & & VHAC & $s=10$. & & D. $5 n$. & km & Number of & SITES. & & & & & \\
\hline & HFF SITF & CITE & काtक & $\underset{3}{\text { SITF }}$ & SITE & SITE & 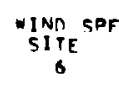 & $\begin{array}{c}\text { EDS } \\
\text { SITE } \\
1\end{array}$ & Site & $\underset{9}{\operatorname{SITE}}$ & $\operatorname{sit}_{10}$ & $\begin{array}{l}\text { MEAN OF } \\
\text { SIMULAPED } \\
\text { SITES }\end{array}$ & $\begin{array}{l}\text { AREA } \\
\text { MEAN } \\
\text { SOEED }\end{array}$ \\
\hline$r$ & $1 n . n n$ & 19.44 & 12.33 & 11.81 & 9.00 & 9.97 & 4.36 & A.9n & 9.10 & 11.23 & 9.57 & 7.79 & 10.09 \\
\hline 1 & 11.04 & 2.41 & 17.70 & 11.64 & 7.94 & 9.76 & 11.90 & 7.69 & $15 . A 1$ & 15.30 & 12.34 & 11.41 & 11.06 \\
\hline , & 12.00 & $15.5 n$ & 9.97 & 9.15 & 14.64 & 14.25 & 12.35 & 6.30 & $\ln .03$ & 13.43 & 15.62 & 12.24 & 11.95 \\
\hline 3 & 17.93 & 11.32 & 13.44 & 16.14 & 19.84 & 12.85 & 12.15 & 15.67 & $16 . .0$ & 13.51 & 10.58 & 13.78 & 12.71 \\
\hline 4 & $17.4 \mathrm{~h}$ & 14.57 & 13.20 & 14.35 & $13 . n \mathrm{~Pa}$ & 13.16 & 11.33 & 15.37 & 14.09 & $13 . n s$ & 13.67 & $13.7 \mathrm{~b}$ & 13.29 \\
\hline$=$ & $13 . \mathrm{AR}$ & 17.50 & 11.37 & 16.41 & 19.07 & 16.55 & 15.11 & 17.57 & 12.78 & 11.92 & 12.09 & 14.19 & 13.65 \\
\hline 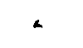 & $14.0 n$ & 13.03 & 0.70 & 12.60 & 15.10 & 13.05 & 14.03 & 11.17 & 13.10 & 10.21 & 16.77 & 13.08 & 13.78 \\
\hline , & 13.84 & 15.36 & 15.45 & $14 . \mathrm{H}_{4}$ & $6.9 \times$ & 9.22 & $1{ }^{R} \cdot 11$ & 13.26 & 12.95 & 14.57 & 17.14 & 13.79 & 13.65 \\
\hline$\therefore$ & 13.66 & 9.09 & 13.98 & 16.83 & 13.46 & 9.73 & 15.54 & 14.08 & 11.74 & 13.12 & 11.31 & 12.96 & 13.29 \\
\hline 2 & 17.27 & $1.3 .7 n$ & 19.03 & 9.73 & $12.9 A$ & 13.76 & 14.52 & 14.24 & 12.92 & 14.59 & 13.29 & 13.47 & 12.71 \\
\hline 11 & 12.00 & 10.79 & 12.01 & 14.77 & 14.10 & 7.33 & 15.01 & $14.5 n$ & 14.56 & 13.29 & 12.11 & 12.85 & 11.95 \\
\hline 11 & 11.114 & 9.13 & 9.97 & 9.91 & 13.51 & 8.26 & 9.29 & 13.14 & 14.66 & 11.41 & 11.65 & 10.99 & 11.06 \\
\hline 12 & $10.0 n$ & 11.47 & 9.45 & $10.9 \mathrm{~A}$ & 10.25 & 12.50 & $9.5 \AA$ & 11.67 & 12.52 & 7.63 & 6.07 & 10.30 & 10.09 \\
\hline 13 & $9.9 \mathrm{~K}$ & 10.55 & 11.61 & 10.55 & 9.26 & 9.13 & 12.07 & 12.14 & 11.65 & 10.47 & 9.31 & 10.60 & 9.11 \\
\hline 16 & 8.00 & 0.70 & 10.42 & 9.80 & 7.62 & 9.68 & 8.13 & 9.49 & 10.09 & 7.59 & 7.34 & 8.90 & 8.20 \\
\hline $1=$ & 7.17 & A. 30 & A.65 & 6.05 & 4.94 & 5.19 & 8.47 & $7.6 ?$ & 7.40 & 5.40 & 6.99 & 0.51 & 7.41 \\
\hline 14 & 0.54 & $4 . n 6$ & 5.53 & H. 71 & 7.80 & 1.33 & 8.94 & 9.05 & 7.24 & 6.99 & 8.27 & 7.17 & 6.81 \\
\hline 17 & A. 14 & 5.48 & $B_{C} A_{B}$ & 6.93 & 6.20 & 6.31 & 7.08 & 5.2 .5 & 6.85 & 6.58 & 8.86 & 6.44 & 6.42 \\
\hline 1. & B.on & 5,52 & 7.46 & $4 . A K$ & 6.38 & 5.67 & 5.95 & $5.0 \mathrm{R}$ & 5.49 & 7.48 & 5.65 & 5.97 & 6.29 \\
\hline 10 & B. 14 & R.9? & 2.43 & 5.73 & 4.09 & 5.10 & 6.59 & 4.66 & 8.83 & 6.81 & 7.36 & 5.84 & 8.42 \\
\hline $2^{n}$ & 6.54 & 4.23 & 4.54 & 4.65 & 3.56 & 6.68 & 8.01 & 6.54 & 7.85 & 6.57 & 6.67 & 6.23 & 6.01 \\
\hline 21 & 1.17 & 5.53 & 7.73 & 7.94 & 8.11 & 8.42 & 6.12 & 9.65 & 6.89 & 5,23 & 10.69 & 1.63 & 7.41 \\
\hline$\gg$ & 9.00 & 7.25 & $A_{0} \cap A$ & 9.39 & $6.6 \mathrm{~A}$ & 5.43 & 9.65 & 10.90 & 6.15 & 1.96 & 4.52 & 1.67 & 8.20 \\
\hline 23 & 8.94 & 10.09 & 5.37 & $8.9 ?$ & 0.52 & 9.23 & 9.70 & 7.56 & $10.8 \mathrm{U}$ & 8.41 & 8.46 & B.53 & 9.11 \\
\hline 24 & 10.00 & 6.76 & n.6n & 9. 36 & 1.12 & 12.03 & 8. 76 & 9.26 & A.17 & 6.46 & 6.61 & 8.12 & 10.09 \\
\hline
\end{tabular}

TABLE B-3. Example Computation of 25 Hours of Input from a Representative Site: Region Diameter $=50 \mathrm{~km}$. (For this example the wind velocity at the representative site was defined by $v_{S}=10+4 \sin \pi t / 12$ where $t$ represented hours.) 
Simulation or Wind SPEFos at pandom SITES

EXAMPLE COMPUTATION

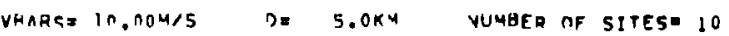

\begin{tabular}{|c|c|c|c|c|c|c|c|c|c|c|c|c|c|}
\hline$H \cap i R$ & SFE SITE & SITF & ${ }_{2}$ & $\begin{array}{c}\text { sith } \\
3\end{array}$ & GITE & SIT & 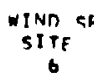 & $\begin{array}{l}\text { ins } \\
\text { sipe }\end{array}$ & StTE & $\underset{9}{\text { SITE }}$ & $\operatorname{site}_{10}$ & $\begin{array}{l}\text { MEAN OF } \\
\text { SI MULATEO } \\
\text { SITES }\end{array}$ & $\begin{array}{l}\text { AREA } \\
\text { MEAN } \\
\text { SDEED }\end{array}$ \\
\hline 1 & ir.on & 10.35 & 11.67 & 20.95 & $9.5 n$ & 10.00 & 6.40 & 0.41 & 9.52 & 10.66 & 9.79 & 9.13 & 10.02 \\
\hline 1 & 11.14 & 9.59 & $1^{2} .79$ & $11.4 ?$ & $9.3 n$ & 19.37 & 11.53 & 0.16 & 13.41 & 13.18 & 11.75 & $11 \cdot 19$ & 11.04 \\
\hline$=$ & $12.0 n$ & $13.5 ?$ & 10.93 & 10.38 & 13.41 & 13.21 & 12.25 & 9.56 & 11.42 & 13.01 & 13.08 & 12.09 & 11.98 \\
\hline 3 & 12.99 & $17 . n A$ & 13.23 & 14.54 & 14.44 & 12.92 & 12.55 & 10.36 & 14.73 & 13.27 & 11.65 & 13.38 & 12.80 \\
\hline 4 & 13.44 & 15.15 & 17.47 & $\{4.03$ & 13.35 & 13.39 & 12.37 & 10.55 & 13.49 & 13,34 & 13.54 & 13.70 & 13.41 \\
\hline 5 & $13.61 k$ & 15.82 & 17.57 & 15.24 & 12.15 & 15.35 & 14.63 & 15.05 & $13.3^{\mathrm{M}}$ & 12.43 & 12.99 & 14.08 & 13.80 \\
\hline$a$ & $1+.00$ & 13.59 & 11.87 & $13.2^{8}$ & 14.73 & 14.57 & 14.13 & $1 ? .5 ?$ & 13.42 & 11.93 & 15.53 & 13.57 & 13.90 \\
\hline 7 & $1 ? .4 \mathrm{k}$ & $14.7^{2}$ & $14.9 n$ & 14.40 & 0.70 & $11 . ? .3$ & 16.11 & 13.64 & 13.44 & 14.35 & 15.66 & 13.02 & 13.80 \\
\hline a & 13.45 & 11.00 & 17.94 & 15.77 & 13.82 & 11.53 & 19.64 & 13.99 & 12.61 & 13.37 & 12.36 & 13.23 & 13.41 \\
\hline 0 & 18.83 & 13.37 & 14.04 & $11.1 \%$ & 12.99 & 13.40 & 13.19 & 13.65 & 12.96 & 13.92 & 13.15 & 13.23 & 12.80 \\
\hline ה: & 12.09 & 11.40 & I $2 . n n$ & 17.47 & 13.14 & 9.28 & 13.59 & 13.37 & 13.31 & 12.74 & 12.12 & 12.45 & 11.90 \\
\hline 11 & 11.04 & 10.01 & $9.9 ?$ & 10.48 & 12.34 & 9.50 & 10.11 & 12.16 & $12 . A 9$ & 11.27 & 11.40 & 11.01 & 11.04 \\
\hline 17 & $1 n . n 0$ & 10.77 & $0.7 ?$ & 10.53 & 10.15 & 11.32 & 9.19 & $10 . \mathrm{AA}$ & 11.24 & 8.07 & 0.21 & 10.13 & 10.02 \\
\hline is & 4.94 & 9.77 & 10.70 & 9.77 & 9.17 & 9.15 & 10.50 & 10.53 & $10.3 n$ & 9.73 & 9.60 & 9.78 & 0.00 \\
\hline 14 & 9.00 & 8.84 & 9.10 & 8.93 & 7.79 & 8.A3 & 0.05 & 8.24 & 9.03 & 7.76 & 7.62 & 0.43 & 8.06 \\
\hline 15 & 7.17 & 7.71 & 5.67 & 6.57 & 5.86 & 6.00 & $P . A_{0}$ & 7.37 & 7.30 & 6.14 & 7.04 & 6.74 & 7.24 \\
\hline $1 n$ & 0.54 & 5.04 & 5.94 & 7.51 & 7.04 & 6.71 & 7.68 & 9.73 & 6.86 & 6.73 & 6.36 & 6.79 & 6.61 \\
\hline 17 & 0.14 & 5.74 & 0.44 & 6.50 & 0.13 & 6.19 & 6.59 & 5.60 & 6.46 & 6.32 & 6.46 & 6.24 & 6.22 \\
\hline If & $6.0 n$ & 5.69 & 6.77 & 5.33 & 0.15 & 5.77 & 5.92 & 5.49 & 3.60 & 0.70 & 5.77 & 5.02 & 6.08 \\
\hline 10 & 9.14 & 7.44 & 3.72 & 9.89 & 4.91 & 5.69 & 6.33 & 5.26 & 0.35 & 6.41 & 6.71 & 5.67 & 6.22 \\
\hline $2 r$ & 6.54 & 5.15 & 5.35 & 5.42 & 6.51 & 6.57 & 7.26 & 6.50 & 7.16 & 6.52 & 6.57 & 6.30 & 6.61 \\
\hline$>1$ & 7.17 & 0.21 & $7: 43$ & 7.54 & 7.62 & 7.77 & 6.56 & 3.36 & 6.99 & 6.04 & 0.83 & 7.33 & 7.20 \\
\hline 27 & R.on & 7.57 & 9.02 & 8.54 & 7.25 & 7.10 & 8.82 & 9.41 & 6.90 & 7.98 & 5.89 & 7.75 & 0.06 \\
\hline$>$ & 0.96 & 9.54 & 6.87 & 8.45 & $9.3 n$ & 7.99 & 9.34 & B.1A & 9.90 & 9.66 & 0.60 & 8.68 & 9.00 \\
\hline 24 & 10.00 & R.13 & 9.03 & 9.11 & 0.73 & 11.05 & 9.34 & 9.58 & 0.34 & 7.04 & 0.03 & 0.03 & 10.02 \\
\hline
\end{tabular}

TABLE B-4. Example Computation of 25 Hours of Input from a Representative Site: Region Diameter $=5 \mathrm{~km}$. (For this example the wind velocity at the representative site was defined by $v_{s}=10+4 \sin \pi t / 12$ where $t$ represented hours.) 
TABLE B-5. Random Numbers Used in the Computation of Tables $\mathrm{B}-2, \mathrm{~B}-3$, and $\mathrm{B}-4$

\begin{tabular}{|c|c|c|c|c|c|c|}
\hline .299 & .454 & .006 & .276 & .306 & . $6 \mathrm{HA}$ & .383 \\
\hline .099 & .277 & .620 & .094 & .990 & .977 & .094 \\
\hline .863 & . A19 & .541 & . & .314 & .765 & .942 \\
\hline . $A B 7$ & .497 & .398 & $.87 ?$ & .931 & .505 & . 210 \\
\hline .447 & $.45 A$ & .235 & .764 & .591 & .444 & .495 \\
\hline .153 & .946 & .678 & $.9 \geq 6$ & .362 & .253 & .231 \\
\hline . GAR & .650 & .510 & .194 & .386 & .115 & .852 \\
\hline ."1n & $.07 ?$ & .954 & .423 & .397 & .0004 & .997 \\
\hline .572 & .123 & .184 & .599 & .279 & .453 & .233 \\
\hline $.51 \mathrm{k}$ & .634 & .140 & .702 & .507 & .747 & .562 \\
\hline .h01 & .043 & .897 & .855 & .054 & .697 & .501 \\
\hline .459 & .122 & .219 & .813 & .954 & .535 & .517 \\
\hline $.5 \cap 8$ & .AB? & .394 & .764 & .891 & .127 & .075 \\
\hline . 5187 & .522 & .953 & .957 & .918 & .751 & .322 \\
\hline .350 & .801 & .459 & .543 & $.8 \times 4$ & .742 & .294 \\
\hline .167 & .036 & .140 & .530 & .492 & .105 & .37? \\
\hline .695 & .023 & $.94 \mathrm{~B}$ & .954 & .596 & .524 & .337 \\
\hline .414 & .445 & .671 & .191 & $\cdot A \cap 3$ & .523 & .005 \\
\hline .505 & .306 & .378 & .181 & .26 .3 & .915 & .302 \\
\hline $.05 ?$ & $.21 A$ & .524 & .105 & .537 & .590 & .747 \\
\hline .409 & .442 & .795 & .404 & .759 & .412 & .439 \\
\hline .654 & .727 & .201 & .938 & .350 & .090 & .992 \\
\hline .187 & .154 & .795 & .955 & .123 & .422 & .024 \\
\hline .581 & .164 & $.59 \mathrm{~A}$ & .200 & .809 & .339 & .349 \\
\hline $.13 A$ & .819 & .257 & .316 & .257 & .054 & .061 \\
\hline
\end{tabular}



PNL-2523

UC -60

\section{DISTRIBUTION}

No. of

Copies

\section{OFFSITE}

A. A. Churm

DOE Chicago Patent Group

9800 South Cass Avenue

Argonne, IL 60439

G. P. Tennyson

Department of Energy

600 E Street, N. W.

Washington, DC 20545

283 DOE Technical Information Center

Thomas Vonier

AWEA Windletter

2222 Q Street, N. W.

Washington, DC 20008

Dr. Paul B. MacCready, Jr.

AeroVironment, Inc.

145 Vista Avenue

Pasadena, CA 91107

Clarissa Quinlan

Alaska State Energy Office

338 Denali Street

Anchorage, AK 99501

Paul N. Vosburgh

Alcoa Allied Products

Aluminum Company of America

Alcoa Center, PA 15069

Dr. K. C. Spengler

American Meteorological Society

45 Beacon Street

Boston, MA 02108

Ben Wolff

American Wind Energy Association 1000 Connecticut Avenue, N. W.

Suite 1111

Washington, DC 20036
No. of

Copies

Richard Katzenberg

American Wind Energy Association

Natural Power, Inc.

New Boston, NH 03070

E. J. Warchol

Bonneville Power Administration

P. 0. Box 3621

Portland, OR 97208

S. J. Hightower

Bureau of Reclamation

Denver Federal Center

Building 67, Code 254

Denver, C0 80225

M. Ginosar

Cal ifornia Solar Energy Commission

Energy Resources, Conservation and Development Commission

1111 Howe Avenue, Mai1 Stop 15

Sacramento, CA 95825

Robert Ball

Center for the Environment and Man, Inc.

275 Windsor Street

Hartford, CT 06120

Dr. R. J. Hawks

Clarkson College

Potsdam, NY 13676

Dr. R. N. Meroney

Colorado State University

Fort Collins, CO 80523

E. H. Gilmore

Department of Agriculture Agriculture Research Service Bushland, TX 79012 
No. of

Copies

\begin{abstract}
L. A. Liljedah
Department of Agriculture

Agriculture Wind Energy Program

Building 001, Room 126 BARC-West

Beltsville, MD 20705

Douglas G. Fox

Department of Agriculture

Forest and Mountain Meteorology

Rocky Mountain Forest and Range

Experiment Station

240 West Prospect Street
\end{abstract}

Fort Collins, CO 80521

Major T. E. Kullgren

DFCEM

USAF Academy, C0 80840

Jay Tappan

Department of Energy

State of Oregon

Labor and Industries Building

Room 111

Salem, OR 97310

Harry Moses

Department of Energy

Division of Biomedical and

Environmental Research

Mail Stop E-201

Washington, DC 20545

Carl Miner TAN-604

EG\&G Idaho, Inc.

P. 0. Box 1625

Idaho Falls, ID 83401

Dr. Edgar Demeo

Electric Power Research Institute

3412 Hillview Avenue

Palo Alto, CA 94303

Jim Lerner

Energy Resources Conservation and Development Commission

Cal ifornia Solar Energy Office

Mail Stop 15

Sacramento, CA 95825
No. of

Copies

Dr. Olle Ljungstrom

FFA, The Aeronautical Research Institute

Forskningsstationen i Stockholm

Drottning Kristinas Vag 47

S-114 28 Stockholm, Sweden

R. B. Lawford

Fisheries \& Environment

25 St. Clair Ave. East

Toronto, Canada M4T 1M2

Dr. W. Frost

FWG Associates, Inc.

R. R. 3, Box 331

Tullahoma, TN 37388

L. Krawitz

General Electric Company

P. 0. Box 8555

Phitadelphia, PA 19101

R. C. Koch

Geomet, Inc.

15 Firstfield Road

Gaithersburg, MD 20760

C. G. Justus

Georgia Institute of Technology

Atlanta, GA 30332

J. Park

HELION, Inc.

Box 445

Brownsville, CA 95919

Darryl Tompkins

JBF Scientific Corporation

1925 North Lynn Street

Suite 308

Arlington, VA 22209

Dr. J. B. Knox

Lawrence Livermore Laboratory

University of California

P. 0. Box 808

Livermore, CA 94550 
No. of

Copies

Ms. Abbey Page

Maine Office of Energy Resources

55 Capitol

Augusta, ME 04330

S. M. Howard

Meteorology Research, Inc.

P. 0. Box 637

Altadena, CA 91001

V. F. Garrett

Montana Energy and MHD Res. and Dev. Inst., Inc.

P. 0. Box 3809

Butte, MT 59701

J. Konigsberg

Montana Energy Office

Capital Station

Helena, MT 59601.

Phillip French

NASA Scientific and Technical

Information Facility

P. 0 . Box 8757

Baltimore/Washington International

Airport

MD 21240

R. A. Wolf

NASA/Lewis Research Center

Mai1 Stop 500-201

Cleveland, $\mathrm{OH} \quad 44135$

M. J. Changery

National Oceanic and Atmospheric Administration

National Climatic Center

Federal Building

Asheville, NC 28801

R. J. Templin

National Research Council of Canada

National Aeronautical Establishment

M-2 Montreal Road

Ottawa, Ontarjo K1A or 6
No. of

Copies

Ms. Peggy McDonald

N. E. Solar Energy Center

70 Memorial Drive

Cambridge, MA 02142

P. W. Blakeley

New Zealand Electricity

Rutherford House

Lambton Quay

Wellington, New Zealand

M. W. Edelstein

North American Weather Consultants

600 Norman Firestone Road

Goleta, CA 93017

R. B. Corotis

Civil Engineering - Tech.

Northwestern University

Evanston, IL 60201

E. W. Hewson

Oregon State University

Corvaliis, OR 97331

R. de Violini

Pacific Missile Test Center

CODE 3250-3

Point Mugu, CA 93042

S. C. Crow

Posejdon Research

11777 San Vincente Blvd.

Suite 641

Los Angeles, CA 90049

Dr. F. M. Vukovich

Research Triangle Institute

P. 0. Box 12194

Research Triangle Park, NC 27709

Terry 3. Hea $1 y$

Rockwell International

Rocky Flats Plant

P. 0. Box 464

Golden, C0 80401 
No. of

Copies

2 R. E. Akins/J. W. Reed

Sandia Laboratories

Division 5443

P. 0. Box 5800

Albuquerque, NM 87115

R. M. Traci

Science Applications, Inc.

P. 0. Box 2351

La Jolla, CA 92038

D. M. Hardy

Solar Energy Research Institute

1536 Cole Blvd.

Golden, CO 80401

Dr. C. M. Bhumralkar

Stanford Research

Institute, Internationa 1

Men lo Park, CA 94025

C. Jump

US Army Corps of Engineers

Seattle District

P. 0. Box C 3755

Seattle, WA 98124

B. H. Bailey

State University of New York

1400 Washington Ave.

Albany, NY 12222

R. Crowder

Taylor Woodrow Construction, Limited

Taywood House

345 Ruislip Road

Southal 1

Middlesex UBI 2QX

England

Dr. T. Wentink, Jr.

University of Alaska

Fairbanks, AK 99701
No. of

Copies

Dr. P. Yuen

University of Hawai at Manoa

Holmes Hall 240

2540 Dole Street

Honolulu, HI 96822

C. E. Duchon

University of $0 \mathrm{klahoma}$

200 Felgar Street

Norman, OK 73069

Dr. N. K. Wagner

Dept. of Civil Engineering

University of Texas

Austin, TX 78712

Dr. M. Garstang

University of Virginia

Charlottesville, VA 22903

Dr. R. W. Marrs

University of Wyoming

Laramie, WY 82071

David Kapus

Washington State Division of

Engineering and Architecture

106 Maple Drive

O1ympia, WA 98504

Ms. Susan Hosch

Washington State Energy Office

400 E. Union Avenue, lst Floor

OTympia, WA 98504

R. K. Woodruff

Washington Public Power Supply System

P. 0. Box 968

Richland, WA 99352

S. R. Epur

Wichita State University

P. 0. Box 44

Wichita, KS 67208 
No. of

Copies

ONSITE

2 DOE Richland Operations Office

P. 0. Box 550

Richland, WA 99352

G. L. Liffick

H. E. Ransom

38 Battelle-Northwest

Battelle Boulevard

Richland, WA 99352

W. C. Cliff (20)

R. L. Conley

J. C. Doran

R. L. Drake

C. E. Elderkin

M. M. Orgill

W. T. Pennell

E. H. Phinney

J. V. Ramsde 11

D. S. Renne

C. L. Simpson

L. L. Wendel1

Technical Information (5)

Publishing Coordination (2) 
- 